\title{
Investigation of Obesity, Physical Activity and Sedentary Behaviors of Individuals with and Without Autism Spectrum Disorder during the Covid-19 Pandemic Process
}

\author{
Nevzat Demirci ${ }^{a}$, Diajeng Tyas Pinru Phytanza ${ }^{b}$ \\ ${ }^{a}$ Faculty of Sports Science, Mersin University, Turkey \\ ${ }^{b}$ Department of Special Education, Faculty of Education, Universitas Negeri Yogyakarta, \\ Indonesia \\ nevzatdemirci44@ hotmail.com ${ }^{\text {a }}$, diajengtyas@uny.ac.id ${ }^{\text {b }}$
}

\begin{abstract}
Adolescents with autism spectrum disorder (ASD) may be at higher risk compared to their typically developing peers. In this study, it was aimed to compare individuals with and without autism spectrum disorder affected by the Covid-19 pandemic process with their peers in terms of obesity, physical activity and sedentary behaviors. Methods: 64 individuals with ASD and 78 healthy individuals were included in the study. An online questionnaire consisting of sociodemographic data, BMI, physical activity and sedentary behavior habits was applied to the participants. Results: Adolescents with autism spectrum disorders were found to be less physically active and more likely to be overweight and obese compared to their typically developing peers $(0.001 * * *)$. BMI $(\mathrm{kg} / \mathrm{m} 2)$ increased compared to before Covid-19. Sedentary behavior increased during quarantine $\left(0.001^{* * *}\right)$. Participation in physical activity decreased in individuals with autism spectrum disorder. As a result: shows the need for targeted programs to reduce unhealthy weight status and support physical activity opportunities for adolescents with autism spectrum disorders.
\end{abstract}

Keywords: Autism Spectrum Disorder, COVID-19, Obesity, physical activity, Sedentary Behaviors

\begin{abstract}
Abstrak
Remaja dengan gangguan spektrum autisme (ASD) mungkin berisiko lebih tinggi dibandingkan dengan rekan-rekan mereka yang biasanya berkembang. Dalam penelitian ini, bertujuan untuk membandingkan individu dengan dan tanpa gangguan spektrum autisme yang terkena proses pandemi Covid-19 dengan teman sebayanya dalam hal obesitas, aktivitas fisik, dan perilaku menetap. Metode: 64 orang dengan ASD dan 78 orang sehat dilibatkan dalam penelitian. Kuesioner online yang terdiri dari data sosiodemografi, BMI, aktivitas fisik dan kebiasaan perilaku menetap diterapkan kepada para peserta. Hasil: Remaja dengan gangguan spektrum autisme ditemukan kurang aktif secara fisik dan lebih mungkin untuk kelebihan berat badan dan obesitas dibandingkan dengan rekan-rekan mereka biasanya berkembang $(0,001 * * *)$. BMI $(\mathrm{kg} / \mathrm{m} 2)$ meningkat dibandingkan sebelum Covid-19. Perilaku menetap meningkat selama karantina $(0,001 * * *)$. Partisipasi dalam aktivitas fisik menurun pada individu dengan gangguan spektrum autisme. Hasilnya: menunjukkan perlunya program yang ditargetkan
\end{abstract}


untuk mengurangi status berat badan tidak sehat dan mendukung peluang aktivitas fisik bagi remaja dengan gangguan spektrum autisme.

Kata Kunci: Gangguan Spektrum Autisme, COVID-19, Obesitas, aktivitas fisik, Perilaku Sedentary

\section{Introduction}

Various preventive measures have been taken by the World Health Organization (WHO) and governments to prevent the Coronavirus disease (COVID-19), which has caused worldwide concern and turned into a global epidemic (pandemic). Among these measures; The start of the intercity quarantine process, the announcement of curfews, the closure of public areas such as parks and sports fields, public permissions for the chronically ill and the elderly, and the closure of schools. Although the measures taken to combat the epidemic have contributed to many people staying at home around the world, this has led people to a sedentary life at home (Chen, Mao, Nassis, Harmer, Ainsworth, \& Li, 2020; Demirci, 2020). Education programs for children with developmental disabilities who received special education at home, school, hospital or rehabilitation centers of previously physically active individuals, such as Autism Spectrum Disorder (ASD), were suddenly interrupted due to the epidemic (Widiyono \& Mudiono, 2021; Yarimkaya \& Esentürk, 2020). These changes in the daily routines of children with ASD due to COVID-19 have revealed risks that affect different perspectives on their lives.

ASD is a neurodevelopmental disorder characterized by difficulties in communication and social interaction, and its prevalence has been increasing in the last decade. In addition to delays in motor development, individuals with ASD have been shown to have deficiencies in motor skills, lack of participation in daily activities, and decreased motivation to participate in beneficial physical activity (FA) (Stanish et al., 2015; Toptaş Demirci and Demirci, 2020). As stated by WHO, people with ASD constitute a special risk group due to their sedentary lifestyles that increase the risk of chronic diseases such as diabetes, obesity and heart disease (Azizah \& Sudarto, 2021; WHO, 2008). Physical inactivity is a major concern for children with ASD (Garcia-Pastor et al., 2019; Sutopo \& Misno, 2021). This is because children with ASD have fewer opportunities to participate in physical activity and exercise, which puts them at risk of developing other health problems. Studies show that children with ASD have lower levels of physical activity (PA) compared to individuals with normal development (MacDonald et al., 2011; Memari et al., 2013; Toptaş Demirci, 2020). In a study by Dreyer Gillette et al. (2015) found that adolescents with ASD were statistically more likely than their typically developing peers to engage in at least 20 minutes of physical activity, 0 days a week, that made them sweat or breathe hard. Similarly, Stanish et al. (2017) found that adolescents with ASD spent less time in moderate-to-vigorous physical activity (MVPA) compared to typically developing adolescents. Pan et al. (2016), on the other hand, suggested that people with ASD are less physically active and engage in MVPA for a lower percentage of time compared to their typically developing peers. The COVID-19 pandemic may negatively impact the health behaviors of youth with ASD and appears to increase sedentary behavior and screen time due to quarantine, while serving as a potential barrier to participation in PA (Demirci et al., 2021; Irawan \& Limanto, 2021; Widodo \& Najibuzzamzam, 2021).

Physical inactivity is an ongoing global health problem (Demirci et al. 2020). During the Covid-19 epidemic, sedentary behaviors such as increased physical inactivity and TV watching time in both normal and ASD children have been associated with increased weight 
gain in children and adolescents (Sisson et al., 2010). Given the deficits in motor development and motor skills, as well as social impairment, these barriers may limit the opportunities for children and adolescents with ASD, individuals with special needs to participate in physical activity and encourage unhealthy increases in sedentary behavior (Toptaş demirci and Tzarova, 2021). In one study, McCoy et al. (2016) found that adolescents with ASD aged 10-17 years were significantly more likely to be overweight $(27 \%)$ and obese (72\%) compared to their typically developing peers. More recently, Healyet al., (2019), although they did not significantly examine the physical activity behaviors of 10-17 year-old adolescents with ASD after controlling for age, race/ethnicity, income, and gender, they found that typically developing It has been suggested that they have higher rates of overweight and obesity compared to their peers. Many factors contribute to the increased likelihood of sedentary behavior and obesity in children with ASD (Hinckson et al., 2013). In addition, the limitations experienced by children with ASD in the areas of social, cognitive, behavioral and physical development negatively affect their physical activity levels (Bandini, et al., 2013). Also, low PA levels combined with high sitting times can be particularly problematic for individuals with ASD. Given the importance of obesity, FA and sedentary behaviors in adolescents with ASD, it is critical to determine whether they will be affected by the pandemic. Therefore, the aim of this study was to focus on the comparison of individuals with and without autism spectrum disorder affected by the Covid-19 pandemic process with their peers in terms of obesity, physical activity and sedentary behaviors.

\section{Research Methodology}

\subsection{Participants}

After the parents of children with ASD were asked to fill in the questionnaire, and healthy children themselves, information about the study was given to the participants using online Google Forms and sent via e-mail and WhatsApp. The questionnaires obtained from the participants were prepared and care was taken to protect all personal data. Inclusion criteria in the questionnaire used in the research process, only healthy individuals between the ages of 12 and 17 who were diagnosed with ASD were allowed to be included, and a voluntary participation consent form was filled. After the data obtained from the questionnaires were collected, the forms were verified by making comparisons, and the forms containing incorrect or incomplete information or contradictory information were excluded from the study. 64 individuals with ASD and 78 healthy individuals were included in the study. An online questionnaire consisting of sociodemographic data and physical activity habits was administered to the individuals. The study was conducted in accordance with the Declaration of Helsinki and current privacy law, and the data was processed. Since we conducted an anonymized survey online, no formal agreement with the ethics committee was requested.

\subsection{Data collecting}

\subsubsection{BMI classification}

BMI classification; Parents of children with ASD were calculated using self-reported child height and weight of normal children and then classified using the Expert Committee Recommendations. underweight $(\mathrm{BMI}<5 \%$ ), normal weight $(\mathrm{BMI}>5$ th percentile and $<85$ th percentile), overweight (BMI $\geqslant 85$ th percentile and $<95$ th percentile), and obese (BMI $\geqslant 95$ th percentile) ( Barlow \& Expert Committee, 2007). 


\subsubsection{Physical Activity}

Regular physical activity; The parents of children with ASD were determined according to the answer given by the normal children to the question "How many days did this child exercise in the last week, did sports or participated in physical activity for at least 60 minutes". Responses varied on a 4-point scale ("never", "1 day", "3 days" and "every day"). A dual classification of "regular physical activity" was defined as "daily" consistent with physical activity recommendations for adolescents (US Department of Health and Human Services, 2008).

\subsubsection{TV Viewing Time}

Parents of children with ASD were asked "on an average weekday, how much time this child usually spends watching TV shows, videos or video games in front of the TV," as reported by normal children themselves. Responses were ranked on a 6-point scale ("never", "less than 1 hour", "1 hour", "2 hours", "3 hours" and "4 or more hours"). TV viewing time was then divided into $<2$ hours/day and $\geqslant 2$ hours/day based on American Academy of Pediatrics recommendations for children and adolescents (American Academy of Pediatrics, 2001).

\subsubsection{Statistical Analysis}

Standard deviations, percentages and frequencies were calculated according to the analysis means and sociodemographic characteristics. Factors associated with the development of three indicators (ASD and BMI classification, weekly physical activity, TV viewing time) before/during lock-in (increase, similarity, decrease) were examined by Pearson's chi-square test. Univariate comparisons between groups and variables were investigated using Fisher's exact test for categorical data or non-parametric Wilcoxon rank-sum test when appropriate for continuous data. Statistical significance was taken at the level of $<0.05$.

\section{Results and Discussion}

\subsection{Result}

Sociodemographic characteristics of individuals with ASD and normal individuals are presented in Table 1. 43.6\% $(n=28)$ of the participants with ASD were female and 56.4\% $(n=36)$ were male, with a mean age of $15.00 \pm 1.75 .51 .3 \%(n=40)$ of normal individuals are female and $48.7 \%$ are male, with a mean age of $16.35 \pm 1.73$ years. We found statistically significant differences in participants regarding sociodemographic variables: age, height, BMI before and during covid-19 $\left(0.05^{*},<0.01^{* *}\right)$. Especially during the quarantine, both men and women gained weight. It was determined that there was an increase in the overweight and obese states of the participants during the Covid-19 process $(<0.001 * * *)$ (Table 1$)$. 
JUMORA: JURNAL MODERASI OLAHRAGA Investigation of Obesity, Physical Activity and Sedentary Behaviors of Individuals with and Without Autism Spectrum Disorder during the Covid-19 Pandemic Process E ISSN: 2797-8761

Sports Education Study Program, University of Ma'arif Nahdlatul Ulama Kebumen

Table 1. The Comparison of sociodemographic characteristics of Individuals with ASD and Normal

\begin{tabular}{|c|c|c|c|c|c|}
\hline & \multicolumn{2}{|c|}{ Adolescents With ASD } & \multicolumn{2}{|c|}{$\begin{array}{c}\text { Normal Developing } \\
\text { Adolescents }\end{array}$} & \multirow[b]{2}{*}{ p-Value } \\
\hline & $\begin{array}{l}\text { Female } \\
(n=28)\end{array}$ & $\begin{array}{c}\text { Male } \\
(\mathrm{n}=36)\end{array}$ & $\begin{array}{l}\text { Female } \\
(n=40)\end{array}$ & $\begin{array}{c}\text { Male } \\
(\mathrm{n}=38)\end{array}$ & \\
\hline Age (years) & $14.40 \pm 1.65$ & $\begin{array}{l}15.60 \pm \\
1.85\end{array}$ & $16.20 \pm 1.71$ & $16.50 \pm 1.76$ & $<0.05^{*}$ \\
\hline $\begin{array}{lll}\text { Weight } & (\mathrm{kg}) & \text { before } \\
\text { Covid-19 } & & \end{array}$ & $63.2 \pm 11.1$ & $60.3 \pm 10.1$ & $59.0 \pm 10.1$ & $66.4 \pm 11.6$ & $<0.01 * *$ \\
\hline Current weight (kg) & $72.2 \pm 13.8$ & $70.1 \pm 12.5$ & $63.2 \pm 11.8$ & $70.6 \pm 13.2$ & $<0.01 * *$ \\
\hline Height $(\mathrm{cm})$ & $168.4 \pm 7.2$ & $173.2 \pm 7.4$ & $167.5 \pm 6.2$ & $175.4 \pm 9.2$ & $<0.01 * *$ \\
\hline $\begin{array}{l}\mathrm{BMI}(\mathrm{kg} / \mathrm{m} 2) \quad \text { before } \\
\text { Covid-19 }\end{array}$ & & & & & \\
\hline Underweigh $\mathrm{t}^{\mathrm{a}}$ & $2(\% 7.1)$ & $3(\% 8.3)$ & $5(\% 12.5)$ & $3(\% 7.8)$ & $<0.01 * *$ \\
\hline Normal $^{b}$ & $12(\% 42.9)$ & $18(\% 50.0)$ & $25(\% 62.5)$ & $27(\% 71.0)$ & \\
\hline Overweight $^{c}$ & $8(\% 28.6)$ & $8(\% 22.3)$ & $6(\% 15.0)$ & $5(\% 13.3)$ & \\
\hline Obese ${ }^{\mathrm{d}}$ & $6(\% 21.4)$ & $7(\% 19.4)$ & $4(\% 10.0)$ & $3(\% 7.9)$ & \\
\hline \multicolumn{6}{|l|}{ BMI (kg/m2) current } \\
\hline Underweigh $\mathrm{t}^{\mathrm{a}}$ & $2(\% 7.1)$ & $3(\% 8.3)$ & $4(\% 10.0)$ & $3(\% 7.8)$ & $<0.001 * * *$ \\
\hline Normal $^{b}$ & $8(\% 28.6)$ & $12(\% 33.3)$ & $27(\% 67.5)$ & $25(\% 65.7)$ & \\
\hline Overweight $^{c}$ & $12(\% 42.9)$ & $12(\% 33.3)$ & $4(\% 10)$ & $6(\% 15.7)$ & \\
\hline Obese $^{\mathrm{d}}$ & $6(\% 21.4)$ & $9(\% 25.1)$ & $5(\% 12.5)$ & $4(\% 10.8)$ & \\
\hline
\end{tabular}

Body Mass Index (BMI), ${ }^{a}$ underweight (BMI $<5$ th percentile), ${ }^{b}$ normal weight $(\mathrm{BMI})>5$ th percentile and $<85$ th percentile), ${ }^{\mathrm{c}}$ overweight (BMI) $\geqslant 85$ th percentile and $<95$ th percentile), ${ }^{\mathrm{d}}$ obese (BMI) $\geqslant 95$ th percentile)

While the rate of women with ASD participating in activities never a week during Covid-19 is $53.6 \%$, it is $30 \%$ for normal individuals. While the rate of men with ASD was $66.7 \%, 21 \%$ of normal men participated. It is seen that $28.6 \%$ of women with ASD and $16.6 \%$ of men participate in physical activity 1 days a week. For normal individuals, $42.5 \%$ of women and $52.5 \%$ of men participated in physical activity 1 days a week. In both groups, $83 \%$ of women and $87.7 \%$ of men performed moderate physical activity $<30$ min for one week. It was observed that they allocated time under $(0.001 * * *) .3 .6 \%$ of women with ASD and $5.5 \%$ of men stated that they exercise every day of the week $(0,001 * * *)$. Also, BMI $\left(0.001^{*}\right)$ during Covid-19 Both men and women with ASD gained weight, especially during the quarantine period. It was determined that there was an increase in the overweight and obese status of the participants during the Covid-19 process $\left(<0.001^{* * *}\right)$. In addition, it was determined that there was an increase in sedentary behavior (Television viewing time) in both groups during the covid-19 process $(<0.001 * * *)$ (Table 2$)$. 
JUMORA: JURNAL MODERASI OLAHRAGA

Investigation of Obesity, Physical Activity and Sedentary Behaviors of Individuals with and Without Autism Spectrum

Disorder during the Covid-19 Pandemic Process

E ISSN: 2797-8761

Sports Education Study Program, University of Ma'arif Nahdlatul Ulama Kebumen

Table 2. The Comparison of BMI, Physical Activity and Sedentary Behavior Variables of Individuals with ASD and Normal

\begin{tabular}{lccccc}
\hline & \multicolumn{2}{l}{ Adolescents With ASD } & \multicolumn{2}{c}{$\begin{array}{c}\text { Normal Developing } \\
\text { Adolescents }\end{array}$} \\
& Female & Male & Female & Male & p-Value \\
& $(\mathrm{n}=28)$ & $(\mathrm{n}=36)$ & $(\mathrm{n}=40)$ & $(\mathrm{n}=38)$ & \\
\hline BMI $(\mathrm{kg} / \mathrm{m} 2)$ current & & & & & \\
\hline Underweigh t $^{\mathrm{a}}$ & $2(\% 7.1)$ & $3(\% 8.3)$ & $4(\% 10.0)$ & $3(\% 7.8)$ & $<0.001 * * *$ \\
Normal $^{\mathrm{b}}$ & $8(\% 28.6)$ & $12(\% 33.3)$ & $27(\% 67.5)$ & $25(\% 65.7)$ & \\
Overweight $^{\mathrm{c}}$ & $12(\% 42.9)$ & $12(\% 33.3)$ & $4(\% 10)$ & $6(\% 15.7)$ & \\
Obese $^{\mathrm{d}}$ & $6(\% 21.4)$ & $9(\% 25.1)$ & $5(\% 12.5)$ & $4(\% 10.8)$ & \\
\hline
\end{tabular}

Television viewing time

$(\%)$

$\begin{array}{lccccc}<2 \mathrm{~h} / \text { day } & 8(\% 28.5) & 12(\% 33.3) & 10(\% 25.0) & 10(\% 26.3) & <0.001 * * * \\ \geqslant 2 \mathrm{~h} \text { /day } & 20(\% 71.5) & 24(\% 66.7) & 30(\% 75.0) & 28(\% 73.7) & \end{array}$

Physical activity frequency (\%) days/week (\%)

\begin{tabular}{|c|c|c|c|c|c|}
\hline Never a week & $15(\% 53.6)$ & $24(\% 66.7)$ & $12(\% 30.0)$ & $8(\% 21.0)$ & $<0.001 * * *$ \\
\hline 1 times a week & $8(\% 28.6)$ & $6(\% 16.6)$ & $17(\% 42.5)$ & $20(\% 52.5)$ & \\
\hline 3 times a week & $4(\% 14.2)$ & $4(\% 11.2)$ & $8(\% 20.0)$ & $6(\% 15.7)$ & \\
\hline$>7$ days/week & $1(\% 3.6)$ & $2(\% 5.5)$ & $3(\% 7.5)$ & $4(\% 10.8)$ & \\
\hline
\end{tabular}

Body Mass Index (BMI), ${ }^{a}$ underweight (BMI $<5$ th percentile), ${ }^{b}$ normal weight (BMI) $>5$ th percentile and $<85$ th percentile), ${ }^{c}$ overweight $(\mathrm{BMI}) \geqslant 85$ th percentile and $<95$ th percentile), ${ }^{\mathrm{d}}$ obese $(\mathrm{BMI}) \geqslant 95$ th percentile)

OSB'li ve normal bireylerin pandemi döneminde fiziksel aktivite alışkanlıklarının değişimi üzerindeki etkilerini araştırmak için katılımcılara karantina sırasında fiziksel aktivite alışkanlıklarının değişip değişmediğini sorduk. Şekil 1'de görüldüğü gibi, katılımcılarda sedanter davranışlarda artış tespit edildi $(<0.01 * *)$ (Şekil 1).

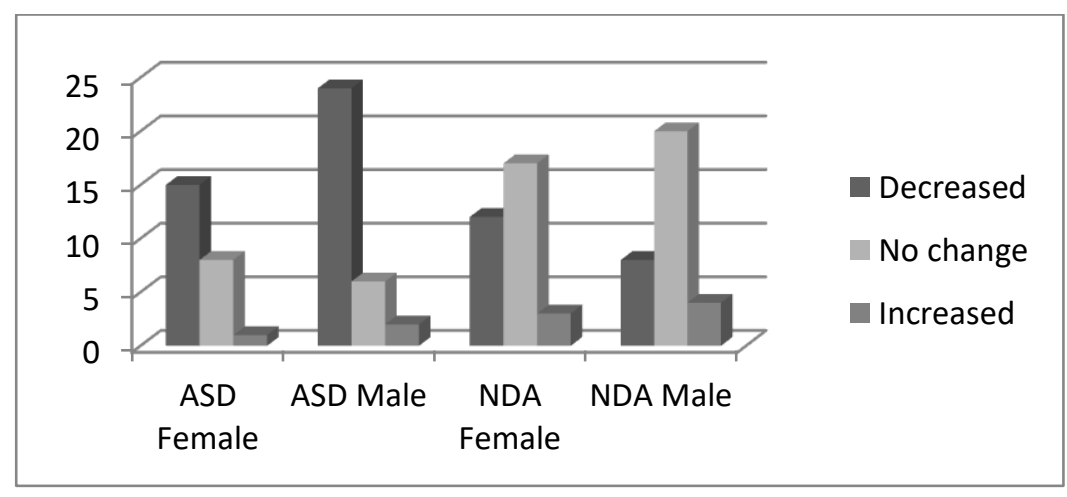

ASD (Autism Spectrum Disorder), NDA (Normal Developing Adolescents)

Figure.1 The change in physical activity habits during the pandemic of Individuals with ASD and Normal 


\subsection{Discussion}

The purpose of this research was to investigate parent-reported changes in health behaviors (physical activity behaviors, BMI classification, sedentary behavior) during the pandemic in individuals diagnosed with ASD and their normal peers, by comparing them with their peers. We hypothesized that adolescents with ASD would be more likely to be overweight or obese, less likely to engage in weekly physical activity behaviors, and more likely to engage in sedentary behaviors such as watching TV. ( $\geqslant 2$ hours/day). The findings in this study support the hypothesis that adolescents with ASD are more likely to be overweight or obese and less likely to engage in physical activity behaviors. However, the results of this study do not support our hypothesis that adolescents with ASD would be more likely to engage in sedentary behaviors. In addition, to investigate the effects of ASD and normal individuals on the change in physical activity habits during the pandemic period, we asked the participants whether their physical activity habits changed during the quarantine, and an increase in the sedentary behaviors of the participants was detected.

This novel study highlights the concern regarding differences in health behaviors in adolescents with ASD prior to and during the COVID-19 pandemic. Although preliminary, the findings from the current study provide initial support for the concern that health behaviors, particularly PA, are negatively impacted by the pandemic in adolescents with ASD (Esenturk, 2020). The findings of this study; Adolescents with ASD were $42.9 \%$ more likely to be overweight and $33.3 \%$ more likely to be obese compared to their normally developing peers, while the probability of being obese was $21.4 \%$ in females and $25.1 \%$ in males. These results are consistent with previous research showing that people with ASD are more likely to be overweight or obese compared to their typically developing peers (Healy et al., 2019; McCoy et al., 2016; Segal et al., 2016). Broder-Fingert et al., (2014) examined a database of individuals with and without ASD between the ages of 2 and 20 and found that children and adolescents with ASD were significantly more likely to be overweight and obese than those without. On the other hand, in parallel with our findings, the prevalence of being overweight is higher in individuals with and without ASD (Phillips et al. 2014).

Individuals with ASD were significantly less likely to participate in regular physical activity than their normally developing peers. Individuals with ASD were less likely to engage in regular weekly physical activity. Our findings are consistent with previous research examining physical activity behaviors in this population (McCoy et al., 2016; Pan et al., 2016; Stanish et al., 2017). A study examining the differences in physical activity between 13-21 years old adolescents with and without ASD showed that those with ASD $(n=35)$ spent significantly less time in moderate and vigorous physical activity (Stanish et al., 2017). Another study examining differences in objectively measured physical activity between 12-17 year old adolescent boys with and without ASD showed that those with ASD were generally less physically active and engaged in MVPA for a lower percentage of overall activity (Pan et al. al., 2016).

Uniquely, this study examined the potential mediation of physical activity behaviors on BMI classification. Adjusting for physical activity behaviors decreased associations between ASD and overweight and obesity. Among both children and adolescents (4-17 years), BMI has been found to be inversley related to physical activity, suggesting that as BMI increases, physical activity decreases (Lawson \& Foster, 2016). This suggests that an intervention 
targeting physical activity behaviors may potentially impact unhealthy weight status in the population. Our results for sedentary behavior were mixed. We found that individuals with ASD were significantly more likely to watch TV and play video games for more than 2 hours a day, compared to their typically developing peers. Published studies on this subject are available in some studies showing that individuals with ASD are more likely to engage in sedentary behaviors and that individuals with ASD spend less time engaging in sedentary behaviors compared to their normally developing peers (Ketcheson, Hauck, \& McCoy et al., 2016). In another study, children with ASD found that both weekdays and weekends TV watching time and total screen time were higher than their normally developing peers (Must et al., 2014). These studies support our findings.

\section{Conclusions}

The COVID-19 quarantine period resulted in a marked deterioration in repetitive behavior, social interaction, social communication and emotional response in children with ASD and returned to core values. Given the results, this study provides evidence for physical activity opportunities for individuals with ASD. While more research is needed to determine the feasibility and effectiveness of increasing physical activity in adolescents with ASD, targeted programs are needed to support healthy lifestyles in adolescents with ASD. It is also the first study to provide evidence that individuals with ASD may experience significant decreases in physical activity and increases in screen time levels during the COVID-19 pandemic. Since the duration of the pandemic is unknown, it is critical to understand the effects of COVID-19 on the health behaviors of individuals with ASD so that effective strategies can be developed to reduce the negative impact and protect against possible long-term health risks.

\section{References}

American Academy of Pediatrics. (2001). American Academy of Pediatrics: Children, adolescents, and television. Pediatrics, 107, 423-426.

Azizah, A. R., \& Sudarto, E. P. (2021). Minat Mengikuti Ekstrakurikuler Bola Voli Siswa Smp Negeri 3 Satu Atap Karangsambung Kecamatan Karangsambung Tahun Ajaran 2019/2020. JUMORA: Jurnal Moderasi Olahraga, 1(01), 35-44. https://doi.org/10.53863/mor.v1i01.132

Bandini, L. G., Gleason, J., Curtin, C., Lividini, K., Anderson, S. E., Cermak, S. A., Maslin, M., \& Must, A. (2013). Comparison of physical activity between children with autism spectrum disorders and typically developing children. Autism, 17 (1), 44-54.

Barlow, S. E. \& Expert Committee. (2007). Expert committee recommendations regarding the prevention, assessment, and treatment of child and adolescent overweight and obesity: Summary report. Pediatrics, 120 (Suppl. 4), S164-S192. doi:10.1542/peds.2007-2329C

Chen, P., Mao, L., Nassis, G. P., Harmer, P., Ainsworth, B. E., \& Li, F. (2020). Coronavirus disease (COVID-19): The need to maintain regular physical activity 
while taking precautions. Journal of Sport and Health Science, 9 (2), 103-104. https://doi.org/10. 1016/j.jshs. 2020.02.001.

Demirci N. (2020). Fight Coronavirus Disease (COVID-19): More Active People for a Healthier World: Physical Activity Recommendations. Int J Disabil Sports Health Sci;3(1):1-4 doi:10.33438/ijdshs.731146.

Demirci, N., Demirci, P.T. \& Koz, H. (2021). The Impact of COVID-19 Lockdown Process on Dietary Behaviours and Physical Activity Habits of High School Students. In: Education Quarterly Reviews, Vol.4 Special Issue 1: Primary and Secondary Education, 651-660.

Demirci, N., Toptaş Demirci, P. and Zırhlı, O. (2020). The relationship between physical activity levels and health-related quality of life elderly individuals with aged 65 years and above chronic disease. Balt J Health Phys Act; 12 (3): 103-113. doi: 10.29359/BJHPA.12.3.10

Dreyer Gillette, M. L., Borner, K. B., Nadler, C. B., Poppert, K. M., Odar Stough, C., Swinburne Romine, R., \& Davis, A. M. (2015). Prevalence and health correlates of overweight and obesity in children with autism spectrum disorder. Journal of Developmental \& Behavioral Pediatrics, 36, 489-496.

Esenturk OK. Parents' perceptions on physical activity for their children with autism spectrum disorders during the novel Coronavirus outbreak. Int J Dev Disabil. 2020. https://doi.org/10.1080/20473869.2020.1769333.

Garcia-Pastor, T., Salinero, J. J., Theirs, C. I., \& Ruiz-Vicente, D. (2019). Obesity status and physical activity level in children and adults with autism spectrum disorders: A pilot study. Journal of Autism and Developmental Disorders, 49, 165-172.

Healy, S., Aigner, C. J., \& Haegele, J. A. (2019). Prevalence of overweight and obesity among US youth with autism spectrum disorder. Autism, 23, 1046-1050.

Hinckson, E. A., Dickinson, A., Water, T., Sands, M., \& Penman, L. (2013). Physical activity, dietary habits and overall health in overweight and obese children and youth with intellectual disability or autism. Research in Developmental Disabilities, 34 (4), 1170-1178.

Irawan, Y. F., \& Limanto, D. (2021). Pengaruh Kecerdasan Emosi dan Kesiapan Diri Terhadap Pertandingan Pada Pemain Walet Muda Futsal Academy Kebumen Tahun 2020. JUMORA: Jurnal Moderasi Olahraga, 1(01), 18-26. https://doi.org/10.53863/mor.v1i01.130

Ketcheson, L., Hauck, J. L., \& Ulrich, D. (2018). The levels of physical activity and motor skills in young children with and without autism spectrum disorder, aged 2-5 years. Autism,22, 414-423. 
Lawson, L. M., \& Foster, L. (2016). Sensory patterns, obesity, and physical activity participation of children with autism spectrum disorder. American Journal of Occupational Therapy, 70(5),7005180070p1-7005180070p8.

McCoy, S. M., Jakicic, J. M., \& Gibbs, B. B. (2016). Comparison of obesity, physical activity, and sedentary behaviors between adolescents with autism spectrum disorders and without. Journal of Autism and Developmental Disorders, 46, 2317-2326.

MacDonald, M., Esposito, P., \& Ulrich, D. (2011). The physical activity patterns of children with autism. BMC Research Notes, 4 (1): 422. https://doi.org/10.1186/1756-0500-4-422.

Memari, A. H., Ghaheri, B., Ziaee, V., Kordi, R., Hafizi, S., \& Moshayedi, P. (2013). Physical activity in children and adolescents with autism assessed by triaxial accelerometry. Pediatric Obesity, 8 (2), 150-158. https://doi.org/10.1111/j.20476310.2012.00101.x.

Must, A., Phillips, S., Curtin, C., \& Bandini, L. G. (2015). Barriers to physical activity in children with autism spectrum disorders: Relationship to physical activity and screen time. Journal of Physical Activity \& Health, 12, 529-534. doi:10.1123/jpah.2013-0271

Pan, C. Y., Tsai, C. L., Chu, C. H., Sung, M. C., Ma, W. Y., \& Huang, C. Y. (2016). Objectively measured physical activity and health-related physical fitness in secondary school-aged male students with autism spectrum disorders. Physical Therapy, 96, 511-520.

Phillips, K. L., Schieve, L. A., Visser, S., Boulet, S., Sharma, A. J., Kogan, M. D., . . . Yeargin-Allsopp, M. (2014). Prevalence and impact of unhealthy weight in a national sample of US adolescents with autism and other learning and behavioral disabilities. Maternal and Child Health Journal, 18, 1964-1975.

Segal, M., Eliasziw, M., Phillips, S., Bandini, L., Curtin, C., Kral, T. V., . . . Must, A. (2016). Intellectual disability is associated with increased risk for obesity in a nationally representative sample of US children. Disability and Health Journal, 9, 392-398.

Sisson, S. B., Broyles, S. T., Baker, B. L., \& Katzmarzyk, P. T. (2010). Screen time, physical activity, and overweight in U.S. youth: National Survey of Children's Health 2003. Journal of Adolescent Health, 47, 309-311. doi:10.1016/j. jadohealth.2010.02.016

Stanish, H., Curtin, C., Must, A., Phillips, S., Maslin, M., \& Bandini, L. (2015). Enjoyment, barriers, and beliefs about physical activity in adolescents with and without autism spectrum disorder. Adapted Physical Activity Quarterly, 32, 302317. 
Stanish, H., Curtin, C., Must, A., Phillips, S., Maslin, M., \& Bandini, L. G. (2017). Physical activity levels, frequency, and type among adolescents with and without autism spectrum disorder. Journal of Autism and Developmental Disorders, 47, 785-794.

Sutopo, W. G., \& Misno. (2021). Analisis Kecepatan Tendangan Sabit Pada Pesilat Remaja Perguruan Pencak Silat Tri Guna Sakti Di Kabupaten Kebumen Tahun 2020. JUMORA: Jurnal Moderasi Olahraga, 1(01), 27-34. https://doi.org/10.53863/mor.v1i01.131

U.S. Department of Health and Human Services. (2008). 2008 physical activity guidelines for Americans. Retrieved from https://health.gov/paguidelines/2008/

Toptaş Demirci, P. and Demirci, N. (2020). Theory and Research in Sport Sciences "Physical Activity Practices for Individuals with Down Syndrome Affected by Obesity”, p. 317-334. International Night Library, Ankara, September 2020, ISBN 978-625-7243-58-2.

Toptaş Demirci, P. (2020). Theory and Research in Sport Sciences "Adapted Physical Activity And Physical Education And Sport As A Factor For Social Adaptation And Education Al Integration Of Children With Special Educational Needs: Omtimization Model" s. 161-177. International Night Library, Ankara, September 2020, ISBN 978-625-7243-81-0

Toptaş demirci, P. \& Tzarova, R. (2021). Effect of the Physical Education and Sport Classes on the Physical Capacity of Children with Special Educational Needs. Educational Policy Analysis and Strategic Research, 16(1), 328-355. doi: 10.29329/epasr.2020.334.18

Widiyono, I. P., \& Mudiono. (2021). Keterampilan Dasar Futsal Peserta Ektrakurikuler di SMK Ma'arif 1 Kebumen Tahun Ajaran 2019/2020. JUMORA: Jurnal Moderasi Olahraga, 1(01), 10-17. https://doi.org/10.53863/mor.v1i01.129

Widodo, P., \& Najibuzzamzam, A. (2021). Perbandingan Model Pembelajaran Daring Dan Tatap Muka Penjaskes Mts Darussa'adah Pada Masa Pandemi Tahun Ajaran 2019/2020. JUMORA: Jurnal Moderasi Olahraga, 1(01), 1-9. https://doi.org/10.53863/mor.v1i01.128

World Health Organization (2008). The world health report 2008 - Primary health care (Now more than ever). Geneva: World Health Organization. Retrieved from https://www.who.int/whr/2008/en/.

Yarımkaya, E., \& Esentürk, O. K. (2020). Promoting physical activity for children with autism spectrum disorders during Coronavirus outbreak: benefits, strategies, and examples. International Journal of Developmental Disabilities. 